\title{
A COMPARISON OF INDONESIAN AND SINGAPORE'S POLITICAL SYSTEMS
}

\author{
Esy Maestro ${ }^{1 \mathrm{i}}$, \\ Muhammad Ilham², \\ Rusdinal, \\ Azwar Ananda ${ }^{1}$, \\ Nurhizrah Gistituati ${ }^{1}$ \\ ${ }^{1}$ Universitas Negeri Padang, \\ Indonesia \\ ${ }^{2}$ UIN Imam Bonjol Padang, \\ Indonesia
}

\begin{abstract}
:
The purpose of this study was to illustrate the comparison of the political systems of Indonesia and Singapore. The research method in this paper is a literature study sourced from a collection of books, national and international journals, relevant government pages, and actual news on an official government media pages described descriptively. The results show that Singapore's political system tends to be better than Indonesia because it has clear rules on the source and transparency of the use of political party funds. Through the review of a number of journals, it is expected that Indonesia can implement the Singapore government's policy of regulating political party funds so as to prevent corruption of political party funds.
\end{abstract}

Keywords: political systems, Indonesia, Singapore

\section{Introduction}

Political parties are part of the provision of a democratic form of state. Every provision of the state form has differences of democratic state. Some use a dual-party system and some are multi-party. The application of elections and candidates in each party is influenced by the form of party provisions and political parties. This is because political parties have masses and interests that are in accordance with the ideology of the party they carry, such as countries that tend to use a multi-party system is Indonesia and Singapore.

In political parties, the calculation design of each party is interesting to research. Political parties have the authority at government to coordinate activities so that the

${ }^{i}$ Correspondence: email esymaestro@gmail.com, mhdilham@uinib.ac.id 
public can become voters of the party they are carrying so that the party can win the general election. Before the general election, every political party carried out a campaign and all supplies. Political party programs require a lot of calculation. Elections and democracy require a large financial calculation so the party must seek funding from all aspects involved.

Then the problem arises is whether the calculation of finance is inevitable and how open is the use of financial calculations of political parties? If at the time of a political party's campaign a manipulative financial calculation is carried out in agreed funds, what happens next if the candidate of a political party has already won or taken office? Whether the pattern of behaviour of candidates in elections affects the financial calculations that have been issued when campaigning. Will there be manipulation of financial affairs of political parties as elections? Could political parties carry out manipulation of financial calculations to gain seats in government? The questions that arise are things that need to be evaluated based on the openness of the financial calculations of political parties.

Indonesia and Singapore are neighbouring countries. Both are democracies and use a multi-party system. Nevertheless, the similarities in these two countries are very inversely proportional, especially regarding financial manipulation. One reason is that Singapore has systems and rules governing financial calculations. This system is implemented so that the level of financial manipulative can be minimized. In contrast to Indonesia which is still powerless in the arrangement of financial calculations and openness of political parties so that there is a lot of financial manipulation by candidates who have won a politic party (Funston, 2001).

The formulation of problems in this study is (1) how the concept of financial calculation of political parties; (2) how does the political calculation system of the party compare to financial manipulation in Indonesia and Singapore? and (3) how is the application of financial calculations to the level of financial manipulation? The purpose of this research is to find out the concept of financial calculation of political parties, comparison of financial calculations of political parties and their openness in Indonesia and Singapore, and the application of openness of financial affairs of political parties to the level of financial manipulation.

This research is expected to be published as an additional reference to regulate the financial openness system of political parties in Indonesia so that the case of financial manipulation can be minimized, expand knowledge about the concept of political parties, especially financial calculations, and become an academic discussion to illustrate the comparison of political party systems in Indonesia and Singapore.

\section{Literature Review}

In this subchapter discusses relevant research related to the political system of Indonesia and Singapore.

Efendi and Lien (2020) analysed the comparison of the curriculum in Elementary Education between Indonesia and Singapore. This method of writing uses a library study 
that is classified and analysed in each variable. Literature reviews of some articles can be analysed and draw conclusions from the solutions found. The results showed that Education reforms in Singapore tend to be more advanced when compared to Indonesia because they place more emphasis on outcomes and processes.

Saadah (2019) researched comparative studies of Education reform in Singapore and Indonesia. The writing of this article uses a descriptive qualitative approach to analytics with library research through the collection of a number of journals, notes, and reports related to education reform in Singapore and Indonesia. The results of this study show that the policies made by the Singapore government are more effective than Indonesia. This is due to Singapore's Education reform programs, such as thinking school, learning nation, teach less, learn more, and the excellent school model proven effective in creating quality human resources and playing an active role in the global world. Meanwhile, Indonesia's efforts in improving the quality of national education in the form of education centralization programs in the framework of school-based management, curriculum 2013, teacher certification programs do not seem to be effective and able to improve the quality of Indonesian Education (Putra, 2017; Syamsurijal, 2018). Assegaf (2015) discusses policy analysis and educational strategy for anti-corruption in Indonesia and Singapore. The method used in this writing is a descriptive qualitative approach through documentation, interviews, and observations. The results showed that Indonesia and Singapore have a set legal basis and rules including corruption and gratification. Although the two countries have implemented the foundations and rule of law in the eradication of corruption, Singapore is more transparent and cleaner because it implements three strategies, namely the implementation of the PCA, the establishment of institutions and the increase in civil servants' salaries.

Fionna (2008) discusses political parties in Singapore, Malaysia and Philippines: Reflection of Democratic Tendencies. His research shows that Singapore has an authoritarian and non-democratic political system rather than Malaysia and the Philippines because it is able to suppress opposition parties (Mauzy, and Milne, 2002). This resulted in limited contact and knowledge that they were not effective enough if Singapore was unable to control the party from political life. Unlike Malaysia which embraces a semi-democratic political system with multi-ethnic parties, although corruption of campaign funds still cannot be completely eliminated. Malaysia has not been able to overcome differences between parties because of the difficulty of interethnic bridged between other. In contrast to the Filipinos the concept of opposition parties lacks party loyalty because public figures are practically not involved parties (Case, 1997; Case, 2001).

\section{Material and Methods}

This research method uses literature studies based on book references, such as books, academic journals, relevant government pages, and actual news on official media pages. This study uses descriptive qualitative method to describe the results of research from several journals reviewed. 


\section{Results and Discussion}

This comparison Indonesian and Singapura Political system focus on the concept of financial calculation of political parties, the political calculation system of the party compared to financial manipulation in Indonesia and Singapore, and the application of financial calculations to the level of financial manipulation.

\subsection{The concept of financial calculation of political parties}

Political parties need financial calculations to carry out their every activity, establishing an equivalent System of Institutions for elections. The pattern of delivery to achieve the target of political party activities focuses on the wider community. This activity costs a lot. Political financial calculations are important, especially election-facing parties, such as providing ideology and influencing and gaining trust and support from the public. This activity can overcome many financial calculations. Finance of calculation is important, especially the political party to face the election. Such financial calculations can be spent legally or illegally in all components of the political structure, the administrative group of political parties. Campaign activities use a lot of their financial calculations.

According to Wilhelm (2011) stated that political parties have a source of financial calculations are:

1) Member dues: in addition to the source of financial calculations, member dues have a role to play in the association between party members. Therefore, there is inequality between party members with different levels of prosperity and if there is no financial openness in the privacy of the party. Thus, the party has an open financial structure.

2) Financial calculation of party members: in addition to the calculation of membership sourced from the party contributes to the party that favors it.

3) Round of party capital: a number of parties have Institutions to support party income and rotate capital

4) Donations: financial sources tend to be influenced by the party with the interests brought by the grant from the donator

5) Financial support: finance stems from problems, especially the party's inability to re-finance the loaned. The use of this method needs to be taken into account by the party chairman

6) Election finance expenditures: general finance obtained from the results of votes obtained by the party during the election.

\subsection{The Political Calculation System of Indonesia}

Political parties according to Law No. 2 of 2002 on political parties are national institutions and form a group of Indonesian citizens on equality and desire to strive and defend the interests of members, communities, nations and countries, and maintain the unity of the Republic of Indonesia in accordance with Pancasila and the Constitution of the Republic of Indonesia in 1945. 
The rise of Indonesian political parties came from the establishment of budi Oetomo institution in 1908 in Jakarta by Dr. Wahidin Soediro Hoesodo. Boedi Oetomo had no political purpose, but Indonesian scholars and historians, was endorsed as the idea of the Institute which later became a political institution.

The Government of Indonesia on November 3, 1945 attempted to approve the formation of political parties to survive the fight for Indonesian independence. This was done by Indonesian political parties that are increasingly mushrooming in Indonesia. Each political party replaces an ideology to cover a particular group in society. Tionghua people are categorized as Tionghoa, Muslims are categorized as Muslims. Political parties are categorized into parties according to deity, nationality, Marxism, and beaches without clear status.

The proliferation of political parties was fortified and minimized to this day. during the old order, on July 5, 1960, President Sukarno declared Presidential Regulation No.13 of 1969 concerning the establishment, maturity, and termination of political parties. On April 14, 1961 the President then decreed the President no.128 of 1961 on the winning party in the selection are the PNI, NU, PKI, Catholic Party, Pertindo, Murba Party, PSII, Arudji, and IPKI, there are two additional parties, yairu parkindo and Perti Islam party. When connected with the understanding of real political parties, in their party there is no unstable political ideology.

However, during the new order, the merger of political parties into the hands of the MPR after the elections took place in 1971 wanted the total party reduced so that it became a money party not focused on political ideology, but on the politics of development. President Soeharto wanted to reconstruct the party. Anxiety occurred in the Islamic party then joined the non-Islamic party became the Indonesian democratic party (PDI) on the basis of the reconstruction. Since then, Indonesia has 3 political party institutions, namely PPP, Golkar, and PDI.

In the post-reform period, political parties wanted The Return to Growth. In the 2004 general election there were 24 political parties, and in 2009 there were 49, and in 2014 there were 15 parties that could be legalized following the general election. In addition, the provision that political parties can participate in the general election is that the party that obtains $25 \%$ of the parties that join and become participants in the election can be reduced. The party needs resources in order to maintain and carry out the basic structure of the party in order to represent the people, improve the ability to compete in elections, and participate in political conflicts. In Law Number 2 of 2011 on Political Parties, the financial calculation of political parties comes from due members', according to the law sourced from the State Budget? APBD is focused on party members and the community (Ufen, 2007).

In accordance with the change of the social structure of society and the arrangement of a complicated democratic government structure, at this time no party is even living off the dues of members. This shows the openness of the party's financial calculations to be carried out. The environment is sourced from APBD and APBN. In other words, the purpose of the party's finances is to maintain an independent party. Therefore, if the financial needs of the party exceed the financial resources of the donator, 
then the party tends to focus on the wishes of donors rather than the interests of members or the people in making decisions.

In 2001, in accordance with PP no. 51/2001, the amount of assistance was sourced from the State Budget of Rp. 1,000 per vote; in 2005 PP no.29/2005 the amount of assistance from the state budget amounted to Rp. 21 million per seat and now in accordance with PP No.5/2009 assisted by a total of Rp.108 per vote. Therefore, election finance amounted to Rp. 16 trillion in 2014. In 2009 a total of 10.4 trillion. According to Pramono Agung, vice chairman of the House of Representatives, with a value of $\operatorname{Rp} 300$ million and more expensive by 6 billion.

All costs are so large, there are several parts in order to create corruption. For the financial openness of the party must be implemented. Indonesia's International Openness (TII) released the results of their research on the financial openness of nine parties. Here are some of the series of openness index scores from the five parties that TII examined:

1) Gerindra: 3.74

2) PAN: 3,64

3) PDIP: 3,10

4) Hanura: 2,41

5) PKB: 2,31

The score range is 1 to 4 . A score of 1 determines the unavailability of information. A score of 2 determines the availability of less than $50 \%$ of information, a score of 3 determines the availability of information over $50 \%$, and a score of 4 determines the availability required is complete. ICW field results data on compliance, news, and examination of the party's finances showed a decrease in the party's obligation for openness and responsiveness. In 2004, out of 48 electoral parties, there were 10 reported financial parties a year. This figure continued to shrink in 2005 to 9 parties from 24 electoral parties as well as in 2006.

Concerns can be made about the party's financial backing. Finances are sourced from interests in elections, or they need program assistance. Financial sources from invalid are affected by the need for strategy preparation. Finance is sourced from costs that are not reported to BPK and KPU and KPK. As for member dues has not been set clearly. Income from members is the acquisition of sequence numbers, and the rights of election participants.

The financial openness of the party assisted from the government is often terabit. BPK research data, there are several factors that cause this to occur are:

1) Party's incomprehension about financial aid arrangements,

2) Absence of general provisions on party finances,

3) Unaccompanied party financial assistance to party spending,

4) Unpayment of taxes,

5) The small amount of financial assistance provided by the State Budget,

6) Disbursement of financial aid at the end of the year,

7) Absence of sanction given to the party.

The Party is a public institution that has a function in maintaining democracy and government control that is transparent, honest, and free from financial manipulation. 
Law no. 14 of 2008 on Public Information Disclosure (UUKIP) states that parties are grouped to public bodies and given their rights and obligations. Therefore, the openness and control of the party's finances is something that needs to be implemented. All parties should be able to support the program. This is regulated in Law No. 8 of 2012 on elections, Chapter VIII campaigns, the tenth part of article 129 to article 140 (Bhakti, 2002).

\subsection{The Political Calculation System of Singapore}

Singapore is one of the most conservative countries in Southeast Asia. Parliamentary republicans can be defined that Singapore has a prime minister as the person who administers the government and the president can be referred to as a symbol of government. The person who sits in the parliamentary seat of the government feels from the winning party members, they are elected through the involvement of many parties in the country of Singapore. The election of members of Singapore's governing parliament stemmed from the election of an opposition party. Meanwhile, the party that will sit in the politic party must be able to meet the standards and provisions that have been designed in the Singapore election law, i.e., every party member comes from a minority Candidate of Singapore.

In Singapore, the determination of prang in parliament and the President is done by electoral means or in Indonesia known as elections. Another similarity with Indonesia is that it introduces each candidate to campaign for a parliamentary seat. However, the campaign is regulated in the Singapore government's regulations on elections. In addition, the Singapore government determines many candidates nominated by any political party to campaign. If the candidate violates the government's provisions, then the candidate will get a penalty in the form of fines, imprisonment, and confiscation.

There are 43 parties in Singapore with some understanding, but there are 10 parties that are in the general election. The party names in question are People's Action Party, Workers' Party, Singapore People's Party, Singapore United Front, National Solidarity Party, United Malays National Organization, Reform Party, Singapore Democratic Alliance. Singapore Democratic Party and Singapore Justice Party. Based all the parties mentioned he bag, there is one party that is active and dominate in Singapore, namely the Singapore People's Party or known as pap. It is the most dominant party since Singapore gained its independence until Singapore is one of the countries with a relatively high level of income today. Even if the party's PAP is the most dominations in the seat of Parliament, but the party always obeys the rules in the process of campaigning in the general election.

Based on the explanation above, the Singapore government determines the path that the party uses to carry out the campaign. All of these provisions have been outlined in the Election Department or Singapore election commission listed on the website so that every Singaporean citizen can be known channer that they use in the party for the implementation of campaign. On its website, the government prevents party candidates from campaigning by going home, distributing brochures, using public transport for campaigns, obeying regulations to conduct campaigns in public places unless they have obtained campaign permits in public places, or in other print media. Party candidates are 
limited in the time to carry out the campaign, which is given 2 days before the general election.

Any party can carry out a campaign requiring a considerable amount of funds. The funds come from individual candidates who participated in the campaign in the general election. However, personal finances have not been able to cover all the costs required in the campaign. Therefore, the Singapore government grants permission to party candidates to obtain funds from sponsors or other companies. The cost of campaigning has been determined by the Singapore government, called the Political Donation Act.

The Political Donation Act has stipulated those parties or candidates who can compete in elections are not allowed to obtain donations sourced from companies or groups from overseas. This was done to prohibit foreign interests from interfering in Singapore and could affect Singapore's social and political life.

If the funds donated by the party candidate do not write the name of the identity will be considered an illegal act and grouped on financial manipulation. These funds are called anonymous funds that are permitted to be used by political parties. The party is allowed to receive as much as $\$ 10,000$ or Rp. $90,000,000$ against other candidates. This is in contrast to anonymous donations of individual candidates determined to amount to $\$ 5000$ or as much as 45 million. this is not a large sum of anonymous donations to candidates. The amount of donations of political parties and individual candidates is given to Singaporean citizens over the age of 21, while companies from Singapore money run their business in Singapore.

The Political Donation Act is governed by budget funds spent by individual parties in the campaign process. In the Parliament Election, the funds the party spent in the campaign process did not mention the amount of funds. However, it is optimal for political parties to vote for a list of $\$ 3.50$ or 31,500 . In contrast to the Parliament Election which is not limited to spending. In Parliament Election has a maximum limit of campaign funds spent as much as $\$ 600,000$ or 5.4 billion. This fund equates to a $\$ 30$ spend of Rp.2,700 for list voters.

In the campaign program conducted by political parties give reported funds that go into political parties. They must report any funds that go into the party's coffers as well as individual cash about the status of the funds used. They describe the funds spent. Political parties provide financial statements to the Returning Office called the election watchdog. After they provide financial statements then check the correctness of the file. The financial files of the party and individual candidates were returned to each candidate and informed the newspaper for news in the Singapore media. Knowing this, Singaporeans will be able to see the funds spent during the campaign by the party and the party candidates, to which party and who received the party's funds during the campaign. This can be proven that Singapore is an open country in informing individual parties and candidates in organizing corruption (Quah, 2012).

Another rule adopted by the Singapore government is to punish individual candidates and those who violate any preconceived correctness. They will get prison sentences and fines and assets. The heaviest contribution in the political Donation Act is 
$\$ 20,000$ of Rp.180,000,000, and will be punishable by 3 years or can get both penalties if they know the financial statements are not genuine.

\subsection{Legislative campaign fund regulations in Singapore}

Singapore has clear rules for determining the source of funds used in each election program, particularly campaigns. According to the Handbook for Parliamentary Election Candidates (2011), there are several campaign rules described as follows.

1) Funding Limit obtained: optimization of funds used by individual party candidates (MP/member of Parliament) in Singapore as much as $\$ 3.50$ per head from the legislator's constituency. Restrictions on members of the party are determined by a group of candidates called the Group Representative Constituency.

2) Payment of Election Agent fees: payments made by each individual candidate and party. Each individual candidate and party make payments to the election agent in the form of loans and donations in every election expenditure,

3) Personally issued election payments are charged to candidates,

4) Election payments are charged to political parties,

5) Provide proof of payment as a track record,

6) Provision of election expenditure reports,

7) Post-election report given 31 days after the announcement of the election results determined by the government.

\section{Conclusion}

Based on the above discussion obtained some conclusions, (1) political party funds come from the cost of the party required in the election. The funds are sourced from member's donations, MPs' contributions, party capital screenings, donations, loan funds, and election campaign expenditures, and government assistance; (2) the rules of election funds for every political party in Indonesia shall be stipulated in Law No.8 of 2012; (3) Singapore has rules in the disclosure of political party funds through the Political donations Act 2000; (4) Indonesia may emulate Singapore in implementing a policy of openness of political party budget funds that tends to cause corruption as a form of return on campaign capital; (5) Indonesia and Singapore have similarities in establishing political party funds, namely similarities in interference with foreign parties so that state and political sovereignty can be maintained stability properly.

\section{Conflict of Interest Statement}

The authors declare no conflicts of interests.

\section{About the Author(s)}

First author, Esy Maestro, works as lecturer at Universitas Negeri Padang, his research interest in education. Second author, Muhammad Ilham, works as lecturer at UIN Imam 
Bonjol Padang, his research interest in cultural history. Third till fifth authors work as lecture at Universitas Negeri Padang, and their research interest in education.

\section{References}

Act Number. 20-year 2001 on amendment of act num. 31 year1999 on corruption action. Act Number. 31-year 1999 on corruption eradication article 2 to article 22.

Assegaf Rachman Abd. 2015. Policy Analysis and Educational Strategy for AntiCorruption in Indonesia and Singapore, International Journal of Asian Social science, 5 (11), 611-625

Bhakti Nusa Ikrar (2002). The Transition to Democracy in Indonesia: Some Outstanding Problems, Conference, Hotel Santika, Jakarta 18 October.

Case, W. (1997). Malaysia: still semi-democratic paradigm. Asian Studies Review, 21, Nos. 2-3.

Case, W. (2001). Malaysia's general elections in 1999: A consolidated and high-quality semi-democracy. Asian Studies Review. Vol. 25 (1).

Efendi Yusuf M and Lien Nancy His (2020). The Comparison of Curriculum in Elementary Education between Indonesia and Singapore, Journal of Teaching and Learning in Elementary Education (JTLEE), 3 (2), 22-36.

Fionna Ulla (2008). Political Parties in Singapore, Malaysia, and Philippines: Reflection of Democratic Tendencies, Makara, Sosial Humaniora, 12 (2), 65-71.

Funston, J. (ed.). (2001). Government and politics in Southeast Asia. Singapore: Institute of Southeast Asian Studies.

Mauzy, D. K. and Milne, R. S. (2002). Singapore politics under the People's action party. London: Routledge.

Pramono, Sidik (2011). Pengendalian Keuangan Partai Politik. Jakarta: Kemitraan bagi Pembaruan Tata Pemerintahan.

Quah Jon (2012). Curbing Corruption in Asian Countries: An Impossible dream? Singapore: ISEAS.

Sa'adah Miftahus (2019). Studi Komparatif Reformasi Pendidikan di Singapura dan Indonesia, Jurnal Pembangunan dan Pendidikan: Fondasi dan Aplikasi, 7 (1), 70-79.

Supriyanto (ed), Didik (2011). Anomali Keuangan Partai Politik Pengaturan dan Praktek. Jakarta: Kemitraan Bagi Pembaruan Tata Pemerintahan.

Supriyanto, Didik (2012). Kebijakan Bantuan Keuangan Partai Politik: Review terhadap PP No. 5/2009 dalam Rangka Penyusunan Peraturan Pemerintah Baru Berdasar UU No. 2/2011, dalam "Dana Kampanye: Pengaturan Tanpa Makna". Jurnal Perludem vol 3 Mei 2012. Jakarta: Yayasan Perludem.

Syamsurijjal Arif (2018). Menilik Pendidikan Karakter di Berbagai negara (Studi Multi Situs di Indonesia, Singapura, dan Jepang), Al Hikmah Jurnal Studi Keislaman, 8 (2), 207-214. 
Ufen Andreas (2007). Political Party and Party System Institutionalization in Southeast Asia: A Comparison of Indonesia, the Philippines, and Thailand, working paper at GIGA Research Programmed: Legitimacy and Efficiency of Political System. makes clear that the materials are being reused under permission of a Creative Commons License. Views, opinions and conclusions expressed in this research article are views, opinions and conclusions of the author(s). Open Access Publishing Group and European Journal of Education Studies shall not be responsible or answerable for any loss, damage or liability caused in relation to/arising out of conflicts of interest, copyright violations and inappropriate or inaccurate use of any kind content related or integrated into the research work. All the published works are meeting the Open Access Publishing requirements and can be freely accessed, shared, modified, distributed and used in educational, commercial and non-commercial purposes under a Creative Commons Attribution 4.0 International License (CC BY 4.0). 